\title{
Natural killer cell-based immunotherapy for lung cancer: Challenges and perspectives (Review)
}

\author{
YONGQIN ZENG ${ }^{1}$, XIUZHI LV ${ }^{2}$ and JUAN DU ${ }^{3}$ \\ ${ }^{1}$ Department of Nephrology, The Affiliated Hospital Guizhou Medical University, Guiyang, Guizhou 550004; \\ ${ }^{2}$ Department of Pulmonary and Critical Care Medicine, Guizhou Provincial People's Hospital, Guiyang, Guizhou 550002; \\ ${ }^{3}$ Beijing Key Laboratory of Emerging Infectious Diseases, Institute of Infectious Diseases, \\ Beijing Ditan Hospital, Capital Medical University, Beijing 100015, P.R. China
}

Received April 7, 2021; Accepted August 3, 2021

DOI: $10.3892 /$ or.2021.8183

\begin{abstract}
Despite the marked success of molecular targeted therapy in lung cancer in this era of personalized medicine, its efficacy has been limited by the presence of resistance mechanisms. The prognosis of patients with lung cancer remains poor, and there is an unmet need to develop more effective therapies to improve clinical outcomes. The increasing insight into the human immune system has led to breakthroughs in immunotherapy and has prompted research interest in employing immunotherapy to treat lung cancer.
\end{abstract}

Correspondence to: Professor Juan Du, Beijing Key Laboratory of Emerging Infectious Diseases, Institute of Infectious Diseases, Beijing Ditan Hospital, Capital Medical University, 8 Jingshun East Street, Chaoyang, Beijing 100015, P.R. China

E-mail: duj656@ccmu.edu.cn

Abbreviations: ADCC, antibody-dependent cell-mediated cytotoxicity; CAR, chimeric antigen receptor; CCL, C-C motif ligand; CTL, cytotoxic lymphocyte; DC, dendritic cell; EGFR, epidermal growth factor receptor; FASL, factor-associated suicide ligand; FBP1, fructose 1,6-biophosphatase; GM-CSF, granulocyte-macrophage colony stimulating factor; HLA, human leukocyte antigen; HSP, heat shock proteins; IDO, indoleamine 2,3-dioxygenase; IFN, interferon; IL, interleukin; ILT, Ig-like transcript; KIR, killer cell immunoglobulin-like receptor; mAb, monoclonal antibody; MDSCs, myeloid-derived suppressor cells; MHC, major histocompatibility complex; MICA/B, MHC class I chain-related protein A/B; NK cell, natural killer cell; NKG2, natural killer group 2; NSCLC, non-small cell lung cancer; OS, overall survival; PBMC, peripheral blood mononuclear cell; PD-1, programmed cell death-1; PGE2, prostaglandin E2; PVR, poliovirus receptor; SCLC, small-cell lung cancer; TAMC, tumor-associated myeloid cell; TGF- $\beta$, transforming growth factor- $\beta$; TIGIT, T-cell immunoglobulin and ITIM domain; TINK, tumor-infiltrating NK; TME, tumor microenvironment; TNF, tumor necrosis factor; TRAIL, TNF-related apoptosis-inducing ligand; Tregs, regulatory T cells

Key words: natural killer cells, lung cancer, tumor microenvironment, immunotherapy
Natural killer (NK) cells, which serve as the first line of defense against tumors, can induce the innate and adaptive immune responses. Therefore, the use of NK cells for the development of novel lung-cancer immunotherapy strategies is promising. A growing number of novel approaches that boost NK cell antitumor immunity and expand NK cell populations ex vivo now provide a platform for the development of antitumor immunotherapy. The present review outlined the biology of NK cells, summarized the role of NK cells in lung cancer and the effect of the tumor microenvironment on NK cells, highlighted the potential of NK cell-based immunotherapy as an effective therapeutic strategy for lung cancer and discussed future directions.

\section{Contents}

1. Introduction

2. Review criteria

3. The biology of natural killer (NK) cells

4. NK cells in the lung under physiological conditions

5. NK cell effect on lung cancer

6. The microenvironment of lung cancer modulates NK cells

7. Prospects for lung cancer treatment: NK cell-based immunotherapy

8. Summary

\section{Introduction}

Lung cancer is the leading cause of cancer-related death worldwide; more than 1.7 million people succumbed to lung cancer in 2018 (1). Based on origin, lung cancer can be divided into small cell lung cancer (SCLC) and non-SCLC (NSCLC), of which NSCLC accounts for $80-85 \%$ of the cases (1). Early lung cancer often lacks symptoms, which may lead to delayed diagnosis and treatment. In the late stage, both SCLC and NSCLC can metastasize to other organs; SCLC can metastasize considerably more rapidly, and patients develop metastatic symptoms (bone pain, nervous system changes such as dizziness and seizures, jaundice, enlarged lymph nodes, and/or other conditions such as syndrome of inappropriate 
antidiuretic hormone and Horner syndrome) faster than those with NSCLC. Due to the large proportion of patients diagnosed with locally advanced or widely metastatic cancer at the time of diagnosis, the 5-year relative survival rate for NSCLC is poor, from $68 \%$ in patients with stage IB disease to $0-10 \%$ in patients with stage IVA-IVB disease (2). Although SCLC is characterized by rapid responses to chemotherapy and sensitivity to radiotherapy, given the early treatment resistance, the 5-year overall survival (OS) is $<10 \%$ (3). Traditional treatments for lung cancer include chemotherapy, radiotherapy and surgery. Fortunately, advances in the knowledge of lung cancer and technologies for its detection have promoted marked progress of theories and molecular methods in diagnosing lung cancer and have revolutionized the relevant therapeutics. Researchers have already extensively described the characteristics of the lung cancer genome, and several major pathways sensitive to targeted therapy have been identified (4). Drugs that target these pathways have improved response and survival in patients with metastatic disease (5), some of which have replaced chemotherapy as first-line treatment drugs. Unfortunately, the efficacy in most patients is limited by the emergence of resistance mechanisms, while these interventions are effective initially $(6,7)$. Therefore, investigation of effective strategies to eliminate these resistant tumor cells is urgently needed.

In recent decades, a series of studies have reported the importance of the immune system in malignant disease control, and immunotherapy has gradually attracted the attention of researchers $(8,9)$. Inducing passive or active antitumor responses by the immune system against malignant tumors is an attractive therapeutic strategy. As a critical part of immune surveillance, natural killer (NK) cells exhibit cytotoxic activity against diverse tumor cell types; furthermore, NK cells bridge the innate and adaptive immune responses (10). With the development of methods to regulate NK cell function and enhance tumor sensitivity to NK cell cytotoxicity and the ability to expand NK cells in vitro and manipulate their homing, numerous NK cell-based immunotherapy methods and strategies have been developed (9). In physiological conditions, lung tissue has a considerable amount of NK cells, which may be important antitumor effector cells of lung tissue. Therefore, immunotherapy strategies based on NK cells may confer great clinical benefit to lung cancer treatment. In the present review, the distribution and function of NK cells, the control effect of NK cells on lung cancer, and the effect of the lung cancer tumor microenvironment (TME) on NK cells were briefly introduced and some NK cell-based immunotherapy strategies were described. Given the advances summarized in the present review, an exciting future for NK cell-based cancer immunotherapy is foreseen and the challenges that remain to be tackled are presented. Although enormous steps have been taken in understanding NK cell biology, more work is required to fully explore the anticancer potential of these cells.

\section{Review criteria}

A search for scientific papers published between 1975 and 2020 focusing on NK cells, lung cancer and NK cell-based immunotherapy was performed in PubMed. The search terms used were 'NK cell', 'lung', 'cancer', 'immunotherapy', 'tumor microenvironment', 'cytokine', 'monoclonal antibodies', 'adoptive transfer', 'CAR', alone and in combination. A total of 176 scientific papers were selected, 117 of which were original studies.

\section{The biology of natural killer (NK) cells}

NK cells are innate lymphocytes that can directly eliminate target cells without prior exposure $(11,12)$ and play a key role in antiviral and antitumor immunity. NK cells, mainly present in the peripheral blood, comprise approximately $15 \%$ of all circulating lymphocytes (13), while they are also distributed in multiple tissues including the liver, lung, skin, kidney and bone marrow. Moreover, based on the expression of CD49a (i.e., integrin $\alpha 1$ ), CD69 and CD103 (i.e., integrin aE) (14-17), NK cells can be subdivided into circulating and tissue-resident NK cells. Tissue-resident NK cells usually display high expression of CD49a, CD103, and CD69 (18). More commonly, researchers subdivide human NK cells into two major subsets with distinct maturation and functional properties according to the expression of CD56 and the antibody binding-Fc receptor CD16 (13). CD56 $6^{\text {bright }} \mathrm{CD} 16^{-} \mathrm{NK}$ cells (approximately $10 \%$ of NK cells in the peripheral blood) are specialized in secreting cytokines and are abundantly located in secondary lymphoid organs (lymph nodes, tonsils, and spleen) (19), most of which exhibit characteristics of tissue-resident lymphocytes and tissue-specific adaptations. Furthermore, they can also reveal cytotoxicity under prolonged stimulation with cytokines such as interleukin (IL)-15, IL-12, and IL-18 (13,20-24). CD56 ${ }^{\text {dim }} \mathrm{CD} 16^{+} \mathrm{NK}$ cells (approximately $90-95 \%$ of $\mathrm{NK}$ cells in the peripheral blood) (12) are potent cytolytic effector cells, which can rapidly secrete pro-inflammatory cytokines such as interferon (IFN) $-\gamma$ and cytotoxic mediators such as granzyme once activated. Most of them exhibit characteristics of circulating cells, but they can also show a resident phenotype while located in the lymph nodes, mucosa, and other parts.

Activation of NK cells is regulated by stimulatory and inhibitory signals $(25,26)$. The activation signals are mainly provided by NKp46, NKp30, NKp44, natural killer group 2 memberD(NKG2D), CD16 and killercell immunoglobulin-like receptor (KIR)-S (27), which usually recognize self-ligands expressed on infected or transformed tissues [known as 'recognize non-self' and 'stress-induced self' (28)]. The inhibitory signals are mainly provided by the classic inhibitor, KIR, which usually identifies diseased cells that are lacking ligands such as major histocompatibility complex (MHC) class I molecules [known as 'missing self' (29)]. Activated NK cells can exert cytotoxicity via several distinct mechanisms: i) They release cytoplasmic particles containing granzymes and perforin through immune synapses with target cells to induce target cell apoptosis (30); ii) they play a role through the tumor necrosis factor (TNF) family (31). They express a death-inducing factor ligand [factor-associated suicide ligand, (FASL)] after activation and induce FAS expression on malignant cells, which leads to target cell apoptosis (32). Moreover, TNF- $\alpha$ produced by activated NK cells can also induce tumor cell apoptosis (33); iii) NK cells secrete various effector molecules (including multiple cytokines, chemokines and growth factors) interacting with dendritic cells (DCs), macrophages, $\mathrm{T}$ cells and endothelial cells to limit tumor 


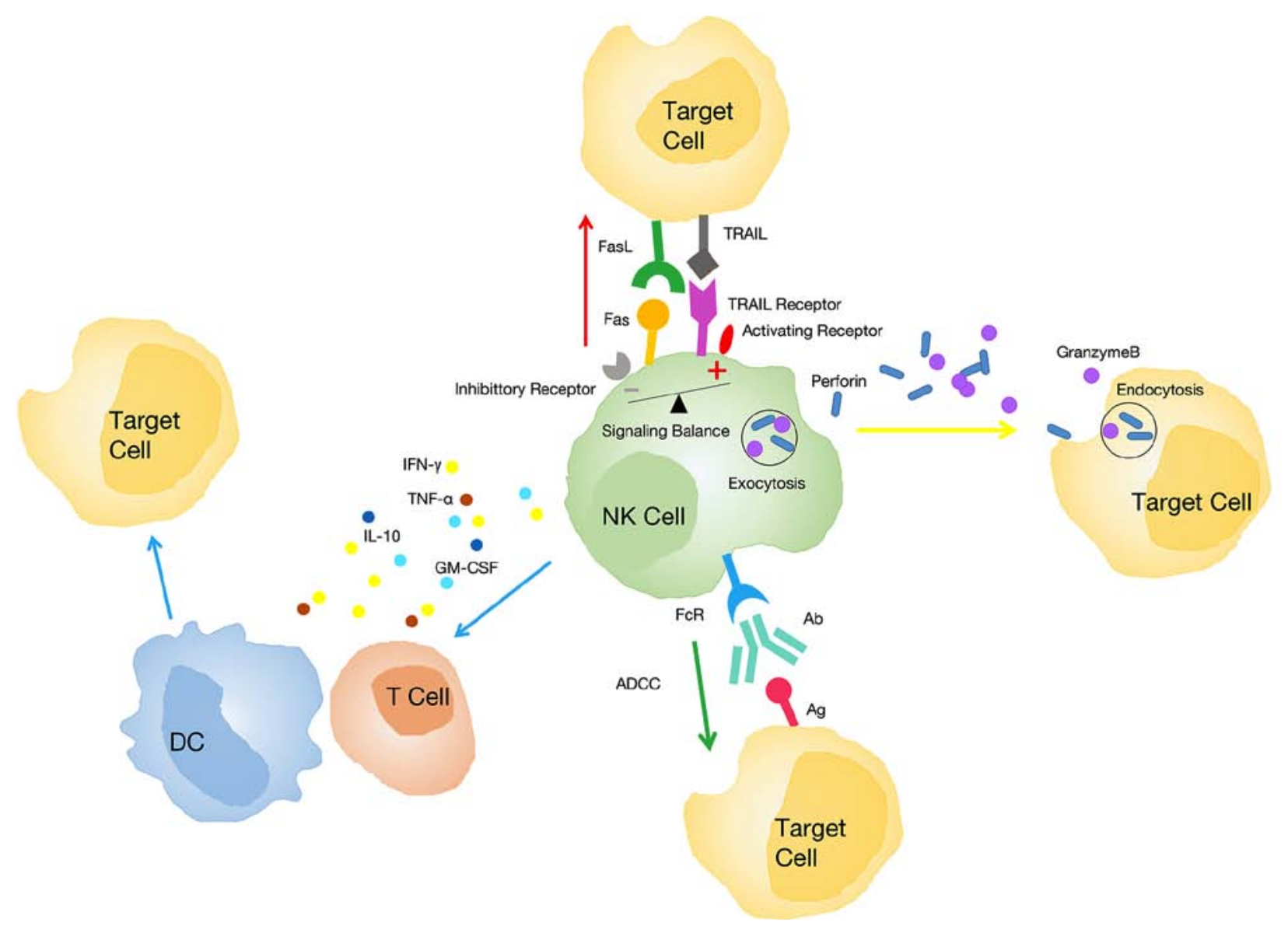

Figure 1. Mechanisms of NK cells exerting cytotoxicity. NK cells induce target cell apoptosis by releasing cytoplasmic particles containing granzymes and perforin (yellow arrow). NK cells play a role through the tumor necrosis factor family (red arrow). NK cells secrete various effector molecules interacting with other immune cells (blue arrow). NK cells eliminate target cells through the ADCC (green arrow). NK, natural killer; ADCC, antibody-dependent cell-mediated cytotoxicity; DC, dendritic cell; FASL, factor-associated suicide ligand; GM-CSF, granulocyte-macrophage colony-stimulating factor; IFN, interferon; IL, interleukin; TNF, tumor necrosis factor; TRAIL, TNF related apoptosis inducing ligand; Ab, antibody; Ag, antigen.

angiogenesis and activate adaptive immunity (10,34-36). For example, IFN- $\gamma$ produced by NK cells increases the expression of MHC class I molecules on transformed cells to promote their recognition by cytotoxic lymphocytes (CTL) (36). Other NK cell-derived factors, including TNF- $\alpha$, IL-10, granulocyte-macrophage colony stimulating factor (GM-CSF), and chemokine C-C motif ligand (CCL)-5, can also regulate the immune response (10); iv) by modifying the Fc portion of $\mathrm{IgG}$ antibodies, NK cells can eliminate target cells through antibody-dependent cell-mediated cytotoxicity (ADCC) (37) (Fig. 1).

\section{NK cells in the lung under physiological conditions}

NK cells exhibit marked mobility, thereby circulating between organs to promote immune surveillance (38). NK cells can respond to multiple chemokines and be recruited to different tissues or inflammation sites owing to the expression of several chemokine receptors (39). The lung is a critical organ of body-environment interaction and is rich in NK cells $(40,41)$. It is generally considered that NK cells originate and develop in the bone marrow and then migrate to the lung (42). The proportion of $\mathrm{NK}$ cells in the lung is similar to, and even slightly higher, than that in the peripheral blood, accounting for $10-20 \%$ of the lymphocytes in the lung (43). IL-15 secreted by bronchial epithelial cells and alveolar macrophages may be responsible for the high proportion of NK cells $(44,45)$ because it is the main cytokine supporting NK cell cytotoxicity, homeostasis, and development $(46,47)$. Unlike the liver and secondary lymphoid organs rich in $\mathrm{CD}^{\text {bright }} \mathrm{CD}^{\text {b6 }}{ }^{-} \mathrm{NK}$ cell subpopulation, most NK cells in the lung exhibit the $\mathrm{CD} 6^{\text {dim }} \mathrm{CD} 16^{+}$phenotype (48), indicating that most are circulating subsets and highly differentiated (49,50). Despite their high differentiation, human NK cells in the lung exhibit a weaker response to target cell stimulation than peripheral blood NK cells (51), which may be attributable to the inhibition of alveolar macrophages (52) and soluble factors of the lower respiratory tract (51). Perhaps because the pulmonary mucosa is continuously exposed to the environment and autoantigens, NK cells with restricted function in physiological conditions may be more conducive to the maintenance of pulmonary homeostasis (49). Although circulating CD56 ${ }^{\mathrm{dim}} \mathrm{CD} 16^{+} \mathrm{NK}$ cells are the major subpopulation in the lung (51), CD49a $\mathrm{a}^{+}$ tissue-resident $\mathrm{NK}$ cells (mainly CD56 $6^{\text {bright }} \mathrm{CD} 16^{-} \mathrm{NK}$ cells) also account for approximately $15 \%$ of human NK cells in this organ (53). Studies have revealed that CD56 ${ }^{\text {bright }} \mathrm{CD} 49 \mathrm{a}^{+}$ NK cells in the lung strongly co-express CD103 and CD69, significantly different from CD56 ${ }^{\text {bright }} \mathrm{CD} 16^{-} \mathrm{NK}$ cells in the peripheral blood $(18,53)$. In in vitro experiments, CD49 $\mathrm{a}^{+}$tissue-resident NK cells exhibited a higher ability 
to degranulate and produce IFN- $\gamma$ when in contact with virus-infected autologous macrophages than NK cells in the peripheral blood (50). Collectively, these results indicated that circulating NK cells in the lung have a larger number and highly differentiated phenotype but exhibit depressed function, while tissue-resident NK cells have stronger function. It is necessary to further study the characteristics of circulating and tissue-resident NK cells in the lung to understand their roles in the physiological condition and in the occurrence and progression of lung tumors, which may provide novel directions for the development of therapeutic strategies.

\section{NK cell effect on lung cancer}

In the 1980s, some studies revealed that cancer incidence was higher among individuals with NK cell dysfunction $(54,55)$. Since then, studies have increasingly confirmed that the antitumor effect of NK cells can act against multiple tumor types $(56,57)$, including head and neck (58), pharyngeal (59), colorectal $(60)$, and lung $(38,61)$ cancers. The direct evidence that NK cells act against lung cancer is supported by Kras-driven spontaneous lung cancer and cancer cell implantation experiments in mice $(61,62)$, both of which revealed that mice lacking NK cells have a greater lung tumor burden. However, the antitumor effect is limited to the early stage of Kras-driven lung cancer in mice due to NK cell dysfunction in the advanced stage (61).

In the past few years, some studies have revealed that NK cells can infiltrate lung cancer and that the number of tumor-infiltrating NK (TINK) cells is significantly associated to postoperative patient survival, indicating that the infiltration of NK cells into tumors may benefit patient prognosis (63-65). Similar phenomena have been observed in patients with breast cancer (66) and renal clear cell carcinoma (67). Interestingly, most TINK cells are of the CD56 ${ }^{\text {bright }}$ CD16- ${ }^{-}$KK type (68), and they only exist in the intratumoral fibrous septum and the interface between stromal and surrounding tumor cells, which appear to indirectly be in contact with cancer cells $(68,69)$. Conversely, in renal clear cell carcinoma, NK cells infiltrate the entire tumor tissue (70). Although the mechanism of TINK enrichment remains unclear, homing restriction and an immunosuppressive microenvironment may play an important role (71-73). A previous study revealed that the proportion of $\mathrm{CD}^{2} 6^{\text {bright }} \mathrm{CD} 16^{-} \mathrm{NK}$ cells in tumoral and non-tumoral lung tissues is similar (74), indicating that the enrichment of $\mathrm{CD}^{- \text {bright }} \mathrm{CD}^{-} 6^{-} \mathrm{NK}$ cells in tumors may be driven by the rejection of $\mathrm{CD} 56^{\mathrm{dim}} \mathrm{CD} 16^{+} \mathrm{NK}$ cells by the tumor. Conversely, it may be related to the chemokine spectrum of CD56 ${ }^{\mathrm{dim}} \mathrm{CD} 16^{+}$ NK cell subsets. For example, it has already been confirmed that the adhesion signal of heterodimerization of chemokine receptor CCR5 (i.e., MIP-1 $\beta$ receptor), which is only expressed by $\mathrm{CD}^{2} 6^{\text {bright }} \mathrm{CD} 16^{-} \mathrm{NK}$ cells, could force leukocytes to stay in the tissue $(75,76)$. In contrast, the viability of CD56 ${ }^{\mathrm{dim}} \mathrm{CD} 16^{+}$ $\mathrm{NK}$ cells may be impaired in the TME. Interestingly, it is generally considered that tumor rejection is mainly due to direct killing by lymphocytes. However, some studies have revealed that IFN- $\gamma$ and other lymphocyte-derived cytokines such as TNF- $\alpha$ can promote tumor rejection to control tumor progression $(77,78)$, which indicates that tumor rejection is a more complicated event than previously considered and that the cytokine secretion function of tumor-infiltrating CD56 $^{\text {bright }}$ CD16 $^{-}$NK cells cannot be ignored in tumor control.

In summary, NK cells can infiltrate and eliminate tumor cells; therefore, targeting NK cells through immunotherapy is an attractive anticancer strategy. Based on the available literature, it can be theorized that the localization of NK cells in tumors (NK cells are most successful in the treatment of hematopoietic malignancies such as leukemia because NK cells are abundant in the peripheral blood) may be an essential factor of NK cell-based immunotherapy. Exploring the role of NK cells in survival and the lung tumor environment may enable the development of methods to improve the ability of NK cells to migrate and infiltrate into tumor tissues, thereby effectively improving the antitumor immunity of the body.

\section{The microenvironment of lung cancer modulates NK cells}

Although it has been determined that NK cells have antitumor effects, malignant tumors continue to develop in the presence of NK cells, which does not mean that NK cells do not contribute to tumor control, but that their antitumor activity may be impaired to some extent $(79,80)$. In this regard, the TME, which is composed of cell components, growth factors, proteases, extracellular matrix, and lymphatic and vascular systems, plays an important role (81). The TME allows tumor cells to obtain cancer markers, establishing a chronic inflammatory environment that maintains tumor growth and induces dysfunction of NK cells in various ways $(79,82)$. An increasing number of studies have revealed that the phenotype and function of $\mathrm{NK}$ cells are altered in the tumor microenvironment (68-69,79). A comprehensive understanding of the factors and mechanisms that cause NK cell changes in the TME may help reveal means to restoring their antitumor potential.

Several mechanisms have been revealed to be related to the phenotype and function alterations of $\mathrm{NK}$ cells (Fig. 2). Firstly, tumor cells can affect the phenotype of NK cells depending on cell-to-cell contact (83). In lung cancer, an in vitro Transwell experiment revealed that the communication between NK and tumor cells is associated with the downregulation of active receptors including NKp30, NKp80, DNAM-1, and NKG2D on the surface of TINKs (69). Another study revealed that the expression of CD155 on tumor cells is related to the downregulation of DNAM-1 on NK cells in NSCLC (84). Conversely, the inhibitory receptors of NK cells are upregulated in cancer. In humans, the expression of T-cell immunoglobulin and ITIM domain (TIGIT) on NK cells was further upregulated in tumor regions compared with peritumoral regions in colorectal tumors (85).

Secondly, the modification of the NK cell phenotype can be altered due to the high expression of immunosuppressive factors such as transforming growth factor (TGF)- $\beta$, indoleamine 2,3-dioxygenase (IDO), IL-4, and prostaglandin E2 (PGE2) (86-89). TGF- $\beta$ has been revealed to be overexpressed in lung cancer cells $(90,91)$, and its expression level can be a prognostic marker in lung cancer (92). Some mechanisms by which TGF- $\beta$ inhibits the function of NK cells have been identified in lung cancer: i) TGF- $\beta$ changes the receptor spectrum of $\mathrm{NK}$ cells in patients with lung cancer $(68,69,93)$. TGF- $\beta$ downregulates the expression of NK 


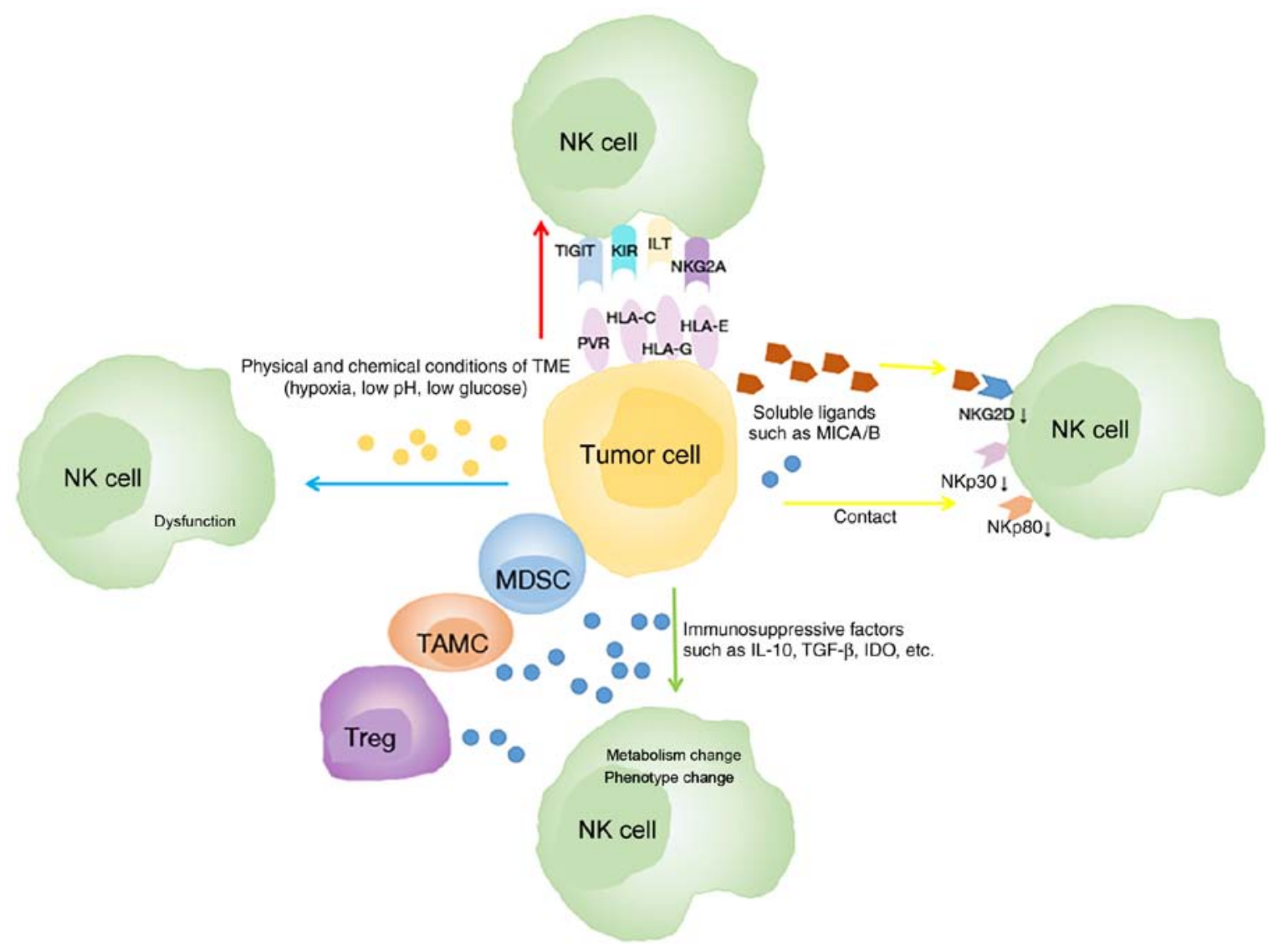

Figure 2. Mechanisms of the microenvironment of lung cancer modulates NK cells. Tumor cells downregulate the expression of active receptors of NK cells (yellow arrow). Tumor cells and some immune cells in the TME secrete immunosuppressive factors which alter the phenotype and metabolism of NK cells (green arrow). The physical and chemical conditions of the TME impair NK cell function (blue arrow). Tumor cells upregulate the expression of inhibitory receptors of NK cells (red arrow). NK, natural killer; TME, tumor microenvironment; HLA, human leukocyte antigen; IDO, indoleamine 2,3-dioxygenase; IL, interleukin; ILT, Ig-like transcript; KIR, killer cell immunoglobulin-like receptor; MDSC, myeloid-derived suppressor cell; MICA/B, MHC class I chain-related protein A/B; NKG2A, natural killer group 2 member A; PVR, poliovirus receptor; TAMC, tumor-associated myeloid cell; TGF- $\beta$, transforming growth factor- $\beta$; TIGIT, T-cell immunoglobulin and ITIM domain; Treg, regulatory T cell.

activating receptors NKp80, NKp30, and NKG2D $(68,69,94)$, thereby inhibiting the cytolytic activity of NK cells $(86,94)$. Neutralizing TGF- $\beta$ inhibits the downregulation of NKG2D expression and restores the antitumor response of $\mathrm{NK}$ cells $(93,95)$; conversely, TGF- $\beta$ upregulates inhibitory receptors including NKG2A (96) and programmed cell death-1 (PD-1) (97) in NK cells in tumors $(96,98)$. ii) TGF- $\beta$ affects the metabolism of NK cells in lung cancer. In Kras-driven lung cancer, high levels of TGF- $\beta$ in the TME cause aberrant expression of the fructose 1,6-biophosphatase (FBP1) protein in NK cells, thereby inhibiting NK cell glycolysis and reducing cellular activity, eventually leading to NK cell dysfunction (61); iii) TGF- $\beta$ mediates NK cell polarization toward angiogenesis (99). Furthermore, another study revealed that the expression of PGE2, which inhibited the antitumor activity of NK cells in NSCLC tumor tissue, was significantly increased (100). Notably, immune cells which are a major component of the TME, inhibit NK cell function mainly by secreting immunosuppressive molecules (101-103). Studies have revealed that the number of myeloid-derived suppressor cells (MDSCs) (104) and regulatory T cells (Tregs) (105) in the lung cancer TME is higher than that in normal tissues and peripheral blood adjacent to cancer, both of which can secrete TGF- $\beta(86,93,106,107)$.
In addition, the physical and chemical conditions of the TME, including hypoxia, low $\mathrm{pH}$ and low glucose concentration, can also impair NK cell function (108). Previous studies have confirmed that hypoxia downregulates the expression of NCR and NKG2D on NK cells (109) and damages their cytotoxicity (110). In NSCLC, high HIF-1 $\alpha$ levels of tumor negatively impact $(111,112)$ the OS of patients; the associated mechanisms may include adenosine generation and accumulation, lactate accumulation and extracellular acidosis. Both adenosine accumulation and extracellular acidosis can block NK cell activation, proliferation and cytotoxicity $(113,114)$, while lactate accumulation mainly inhibits the cytotoxic activity of NK cells and increases the number of MDSCs that inhibit NK cytotoxicity (115).

Clearly, various components of the TME affect the antitumor functional activity of NK cells in different ways during the progression of lung cancer. Among them, TGF- $\beta$ is the main inhibitor of NK cell function. Notably, intratumoral NK cells may have a negative effect on other immune cells located in the TME after their own antitumor function decreases. For example, DC maturation was impaired due to the lack of IFN- $\gamma$ secretion by NK cells and Tregs were profusely recruited through CCL22 secretion induced by NK cells $(116,117)$. An important question is whether the 


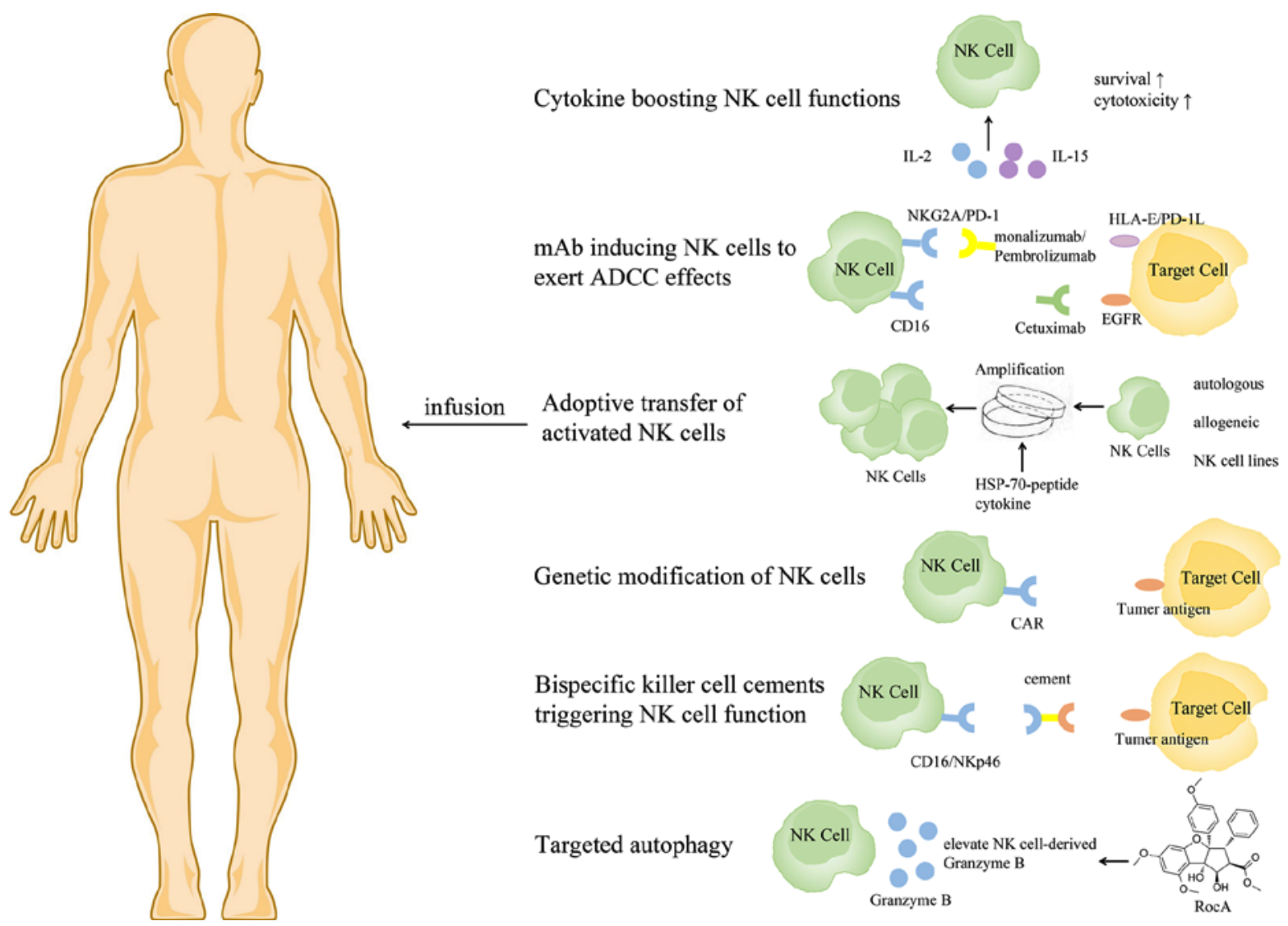

Figure 3. NK cell-based immunotherapies. NK, natural killer; ADCC, antibody-dependent cell-mediated cytotoxicity; CAR, chimeric antigen receptor; EGFR, epidermal growth factor receptor; HSP, heat shock proteins; IL, interleukin; mAb, monoclonal antibody; NKG2A, natural killer group 2 member A; PD-1, programmed cell death-1; HLA, human leukocyte antigen.

modifications in the intratumoral NK phenotype and function are reversible. If they are, enhancing NK cell function with immuno-stimulatory cytokines such as IL-15 or by neutralization of immunosuppressive factors produced in the environment may improve the efficacy of NK cell-based immunotherapy and further ameliorate the clinical outcome of lung cancer.

\section{Prospects for lung cancer treatment: NK cell-based immunotherapy}

Based on the important role of NK cells in tumor control, NK cell immunotherapy has developed rapidly. Several approaches have recently been proposed to boost NK cell antitumor function, to support in vivo persistence and homeostatic proliferation, and to promote homing to the tumor microenvironment (33) (Fig. 3).

Cytokine therapy promotes NK cell proliferation, viability and tumor infiltration. It has been reported that IL-2, IL-15 and IL-18 can enhance the proliferation ability of NK cells and improve their antitumor function $(48,118)$. Meta-analysis results have revealed that IL-2 treatment can significantly improve OS in patients with NSCLC (119). However, IL-2 is not the best choice because Tregs can be preferentially activated by IL-2, thereby inhibiting NK cell proliferation and cytotoxicity $(120,121)$. IL-15 is an alternative form of IL-2, which preferentially stimulates NK cells without activating
Tregs (122). Treatment of drug-resistant solid tumors (including NSCLC) with subcutaneous injection of recombinant human (rh) IL-15 could significantly promote the proliferation of peripheral blood NK cells, especially the proliferation of CD56 $6^{\text {bright }} \mathrm{NK}$ cells, in a phase I non-randomized trial (123). As a super-agonist of IL-15, ALT-803 could encourage the growth of NK cells, induce the expression of NKG2D and the production and release of IFN- $\gamma$, and enhance the role of ADCC (124). In a phase $1 \mathrm{~b}$ clinical trial, patients with metastatic NSCLC treated with ALT-803 and nivolumab exhibited a high tumor response rate and the treatment was well tolerated (125).

Monoclonal antibodies ( $m A b s$ ) that induce $N K$ cells to exert ADCC effects. mAbs that induce NK cells to exert ADCC effects include $\mathrm{mAbs}$ targeting tumor-associated antigens such as rituximab or cetuximab that recognize CD20 and epidermal growth factor receptor (EGFR) and antibodies against inhibitory molecules such as monalizumab that recognizes NKG2A (126-129). Nowadays, immunotherapy targeting the PD-1/PD-L1 inhibitory axis is considered a treatment pillar in NSCLC (130-135). A recent study revealed that TINK cells from patients with NSCLC expressed increasing immune checkpoint receptor PD-1 on their surface, which correlated with their dysfunction (132). Notably, treatment with PD-1 blocking antibodies could reverse PD-L1-mediated inhibition of NK cells (132), highlighting the critical role of PD- $1^{+}$NK cells in immune checkpoint blockade for NSCLC. 
In addition, TIGIT immune checkpoint inhibitors have been revealed to prevent NK cell depletion and elicit effective tumor-specific T-cell immunity in an NK cell-dependent manner (85).

Adoptive transfer of activated NK cells. Adoptive transfer of $\mathrm{NK}$ cells with high yield and high quality is the most direct means to restoring and improving the function of the immune system. The outcome of adoptive transfer of NK cells can vary due to differences in the strategies used for the separation, expansion and activation of NK cells $(136,137)$. NK cells can be derived from either autologous or allogeneic sources, either peripheral blood mononuclear cell (PBMC), stem cell (including umbilical cord blood, embryonic stem cells and induced pluripotent stem cells) or NK cell lines. It has been proven that transferring autologous NK cells into patients is safe (138). An experiment using adoptive NK cells to treat melanoma revealed that the adoptively transferred NK cells persisted in the peripheral circulation of patients for at least 1 week post-transfer and exhibited high levels of lytic activity in vitro but had no effect on tumor regression (139). The limited effect may be attributable to the KIR-ligands of tumors always matching the autologous NK cell KIR repertoire and the suppression by self MHC class I that enables malignant cells to evade NK-mediated elimination. Thus, strategies have been developed to overcome this limitation, such as use of an anti-KIR antibody (140).

Compared with autologous NK cells, allogeneic NK cells persist in vivo and exhibit a clear, improved association with the therapeutic response $(141,142)$. The major risk of using allogeneic NK cells is the development of graft-versus-host disease, which can be improved by the use of haploidentical NK cells (143). A previous study has revealed that after treatment with allogeneic NK cells, the quality of life of patients with advanced NSCLC is improved (130). At present, allogeneic NK cells are widely used in several tumor therapy clinical trials, including acute myeloid leukemia, chronic myeloid leukemia, melanoma, breast and ovarian cancer, neuroblastoma and some types of solid tumors, such as renal cell carcinoma, colorectal and hepatocellular cancer (144).

The source of cells is another issue to consider. Given the small percentage of NK cells of PBMCs, purified NK cells must be expanded ex vivo to attain the requirements for clinical use, but developing strategies to yield an adequate cell number remains a major challenge. Thus, stem cell-derived NK cells are gradually becoming a focus of research. Differentiation of mature, functional NK cells can be achieved through the co-culture of bone-marrow- or umbilical cord blood-derived $\mathrm{CD}^{+}{ }^{+}$hematopoietic stem cells with IL-2/IL-15 and various growth factors (145). Compared with PBMC-derived and stem cell-derived NK cells, NK cell lines are easier to expand. Several cytotoxic cell lines including KHYG-1, NK-92, and NKL are gradually becoming a powerful tool for NK cell-based immunotherapy $(136,137)$. However, the lack of in vivo persistence and CD16 expression in most cell lines limits their clinical use. Fortunately, transgene expression can promote the expression of CD16 (145). Moreover, an in vitro experiment revealed that NK92-CD16 cells have greater cytotoxic potential against tyrosine kinase inhibitor-resistant NSCLC cells than their parental NSCLC cells (146).
Furthermore, to obtain more robust cytotoxic activity of NK cells, immunostimulatory molecules such as cytokines are usually used in combination with NK cells in clinical research. Studies have confirmed that adoptive transfer of NK cells stimulated by IL-15 is effective in the treatment of patients with advanced NSCLC $(130,147)$. Notably, ex vivo heat shock protein (HSP)-70-peptide stimulates NK cells and improves their function. HSPs are usually synthesized when cells react to various stress-inducing or toxic factors (148). Most HSPs are molecular chaperones, and promoting the synthesis of HSPs can improve the function of the chaperone machinery and lead to reduction of cell sensitivity to repeated action of the same or other stressful agents (149). HSPs are overexpressed in various cancers, and their increased expression is generally associated with tumor cell survival, invasion, metastasis and chemoresistance (150-152). A substantial number of studies have reported a relatively higher risk of lung cancer with increased expression of HSP-70, and their levels correlated with the grade and stage of lung tumors $(153,154)$. Another study revealed that membrane-bound HSP-70 acts as a tumor-specific marker enhancing NK cell activity (155). Subsequently, several clinical trials have revealed that ex vivo HSP-70-peptide-activated, autologous NK cells are well tolerated and deliver positive clinical responses in patients with advanced NSCLC (156-158). This may be a promising treatment for lung cancer.

Genetic modification of NK cells. Genetic modification can induce profound and sustained genetic changes in NK cells (159). Among them, chimeric antigen receptor (CAR) NK cells have attracted increasing attention $(160,161)$. The advantages of CAR NK cells over CAR T cells are MHC independence, lack of graft-versus-host response and a relatively limited lifespan (avoiding the need to insert suicide genes into CAR NK cell constructs). Similar to adoptive transfer, the sources of CAR NK cells are diverse and include peripheral blood NK cells, primary cord blood-derived NK cells and the NK cell line NK-92; recent studies have tested their effectiveness $(162,163)$. A previous study has revealed that cord blood NK cells engineered to express IL-15 and a CD19-targeted CAR have long-term persistence and potent antitumor activity and are easy to produce (164). In a phase 2 trial, among 11 patients with relapsed or refractory CD19-positive lymphoid tumors, eight patients exhibited a response to treatment with cord blood-derived CAR-NK cells without the development of major toxic effects (165).

Transformed cell line NK-92, originating from undifferentiated NK-cell precursors, is also commonly used (166). To date, NK-92 has been intensively studied; both preclinical mouse studies and phase I clinical testing have confirmed its safety in patients and cytotoxicity against several tumor types, particularly against lung tumors (167-169). In an in vitro study, a novel chimeric costimulatory converting receptor-modified NK92, which comprised the extracellular domain of PD-1, transmembrane and cytoplasmic domains of NKG2D, and the cytoplasmic domain of 4-1BB, exhibited enhanced antitumor activity against human lung cancer H1299 cells (170). Given that CAR NK cells have favorable application prospects, some measures need to be implemented to develop a more intelligent next generation. First, non-viral vector methods 


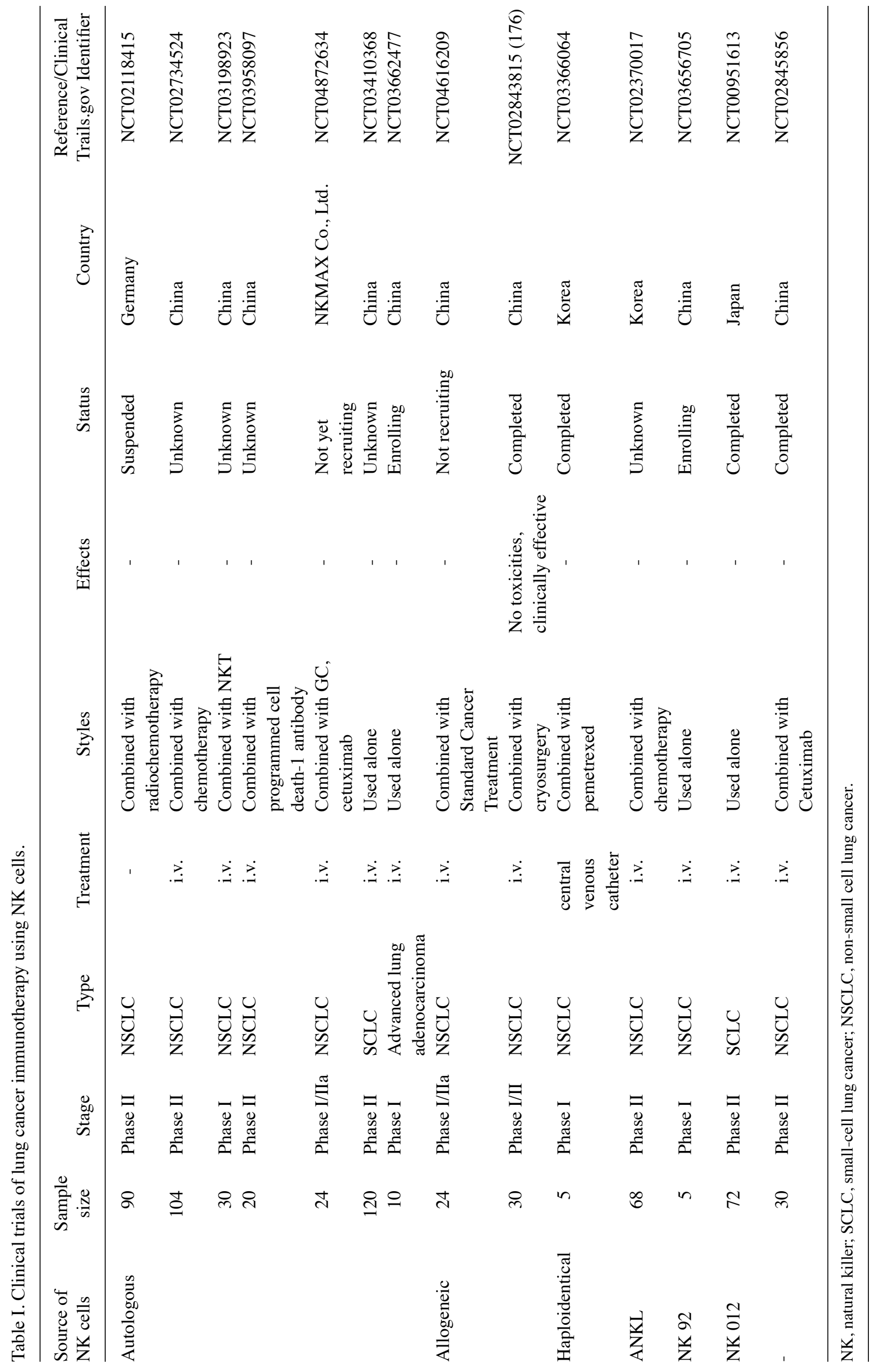


should be developed to avoid the insertion mutations induced by retroviral transfection. Second, establishing improved clinical-grade protocols for purifying NK cells to avoid T-cell contamination which may lead to graft-versus-host disease or lymphoproliferative disorders $(171,172)$. Third, establishing CAR ligand bi-specific CAR molecules or silencing NK inhibitory receptors during the design of CAR-NK cells may further improve the efficacy of CAR-NK cell therapy.

Bispecific killer-cell cements promote lysis of tumor cells by NK cells. Recently, bispecific killer-cell cements have been designed to promote lysis of tumor cells by NK cells $(173,174)$. These NK cell adaptors enable the killing effect of NK cells on tumor cells by targeting activation receptors NKp46 and CD16 via tumor antigens (such as CD19, CD20, or EGFR) and Fc fragments, respectively. Two CD16-based bispecific antibodies with EGFR variants and wild-type EGFR (AFM22 and AFM24) are in preclinical development. In vivo, these antibodies effectively control tumor growth in mouse models of solid and invasive tumors (81).

Targeting autophagy enhances lysis of tumor cells by $N K$ cells. Targeting autophagy is a new strategy in cancer immunotherapy. A recent study revealed that rocaglamide inhibits autophagy and restores the level of NK cell-derived granzyme B in NSCLC, enhances NK cell-mediated lysis of lung cancer cells, and causes tumor regression in vivo (175).

Various applications of NK cells to lung cancer treatment are increasingly being attempted, denoting that there is major progress in NK cell research (Table I). Additional studies in patients with lung cancer are still required to realize the antitumoral potential of NK cells and establish its clinical applications.

\section{Summary}

In recent years, molecular targeted therapy and immune checkpoint inhibitor therapy have led to marked progress in the treatment of lung cancer. However, a considerable number of patients remain unresponsive to treatment, and the need for new treatment strategies is still urgent. Numerous studies have confirmed the critical role of NK cells in lung cancer control. Immunotherapy targeting NK cells may be an effective strategy for lung cancer treatment. The growing insight into the NK cell potential for lung cancer treatment provides a platform for the development of NK-based immunotherapy. However, numerous obstacles remain to be overcome to derive the full benefit of the NK cell antitumor potential. First, the poor ability of NK cells to reach tumor tissues limits their application in solid tumor therapy, which is a common problem with cellular immunotherapy strategies. As aforementioned, when NK cells are present in tumor tissues, they are preferentially localized in the matrix without coming into contact with the tumor cells. Second, changes in NK cell-activated receptors and ligands in tumors may result in decreased antitumor activity. Finally, the TME remains the main obstacle to the effectiveness of the adoptive transfer of NK cells. Despite these challenges, as more data are gathered on the lung cancer TME, immune regulatory cell populations, cancer-related changes in NK cell biology, function, and transport, NK cell immunotherapy will become increasingly effective. Key components to the success of future trials include the incorporation of modalities that harness NK cell cytotoxicity while promoting in vivo survival, homeostatic proliferation, and trafficking to the tumor and the development of drugs that trigger NK cell tumor killing via ADCC or sensitization of the target and drugs that promote NK cell tumor homing, such as the development of monoclonal antibody-chemokine fusion proteins to promote the infiltration of cytolytic NK cells into tumor tissues. Efforts should be made to solve the problems of clonal expansion and genetic modification of NK cells. Currently, several phase I and II clinical trials for the treatment of targeted NK cells for lung cancer are underway, including chemotherapy combined with NK cell adoptive transfer therapy (NCT03366064, NCT03410368), immune checkpoint inhibitors combined with $\mathrm{NK}$ cell adoptive transfer (NCT03958097), surgery combined with NK cell adoptive transfer therapy (NCT02843815), and CAR NK cell therapy (NCT03656705). In the future, combined standard radiotherapy, chemotherapy or radiochemotherapy, targeted therapy, ex vivo stimulation or CAR-NK cells and other targeted NK cell methods may eventually change the treatment mode of lung cancer, providing hope to patients with limited treatment options.

\section{Acknowledgements}

Not applicable.

\section{Funding}

The present work was supported by the National Natural Science Foundation of China (grant no. 81902895), the National Key Sci-Tech Special Project of China (grant no. 2018ZX10302207), the Beijing Natural Science Foundation (grant no. M21007) and the Beijing Hospital Authority (grant no. DFL20191801).

\section{Availability of data and materials}

Not applicable.

\section{Authors' contributions}

YZ conceptualized and wrote the manuscript. XL and JD contributed to the literature review and organization of the manuscript. All authors confirm the authenticity of all the raw data. All authors read and approved the final manuscript.

\section{Ethics approval and consent to participate}

Not applicable.

\section{Patient consent for publication}

Not applicable.

\section{Competing interests}

The authors declare that they have no competing interests. 


\section{References}

1. Yuan M, Huang LL, Chen JH, Wu J and Xu Q: The emerging treatment landscape of targeted therapy in non-small-cell lung cancer. Signal Transduct Target Ther 4: 61, 2019.

2. Goldstraw P, Chansky K, Crowley J, Rami-Porta R, Asamura H, Eberhardt WE, Nicholson AG, Groome P, Mitchell A, Bolejack V, et al: The IASLC lung cancer staging project: Proposals for revision of the TNM stage groupings in the forthcoming (eighth) edition of the TNM classification for lung cancer. J Thorac Oncol 11: 39-51, 2016.

3. Planchard D, Popat S, Kerr K, Novello S, Smit EF, Faivre-Finn C, Mok TS, Reck M, Van Schil PE, Hellmann MD, et al: Metastatic non-small cell lung cancer: ESMO clinical practice guidelines for diagnosis, treatment and follow-up. Ann Oncol 29 (Suppl 4) iv192-iv237, 2018

4. Chen Z, Fillmore CM, Hammerman PS, Kim CF and Wong KK: Non-small-cell lung cancers: A heterogeneous set of diseases. Nat Rev Cancer 14: 535-546, 2014.

5. Mayekar MK and Bivona TG: Current landscape of targeted therapy in lung cancer. Clin Pharmacol Ther 102: 757-764, 2017.

6. Xie Q, Yu Z, Lu Y, Fan J, Ni Y and Ma L: MicroRNA-148a-3p inhibited the proliferation and epithelial-mesenchymal transition progression of non-small-cell lung cancer via modulating Ras/MAPK/Erk signaling. J Cell Physiol 234: 12786-12799, 2019.

7. Fan Q, Hu X, Zhang H, Wang S, Zhang H, You C, Zhang CY, Liang $\mathrm{H}$, Chen $\mathrm{X}$ and $\mathrm{Ba}$ Y: miR-193a-3p is an important tumour suppressor in lung cancer and directly targets KRAS. Cell Physiol Biochem 44: 1311-1324, 2017.

8. Steven A, Fisher SA and Robinson BW: Immunotherapy for lung cancer. Respirology 21: 821-833, 2016.

9. Shimasaki N, Jain A and Campana D: NK cells for cancer immunotherapy. Nat Rev Drug Discov 19: 200-218, 2020.

10. Vivier E, Raulet DH, Moretta A, Caligiuri MA, Zitvogel L, Lanier LL, Yokoyama WM and Ugolini S: Innate or adaptive immunity? The example of natural killer cells. Science 331 44-49, 2011.

11. Herberman RB, Nunn ME, Holden HT and Lavrin DH: Natural cytotoxic reactivity of mouse lymphoid cells against syngeneic and allogeneic tumors. II. Characterization of effector cells. Int J Cancer 16: 230-239, 1975.

12. Kiessling R, Klein E, Pross H and Wigzell H: 'Natural' killer cells in the mouse. II. Cytotoxic cells with specificity for mouse Moloney leukemia cells. Characteristics of the killer cell. Eur J Immunol 5: 117-121, 1975.

13. Cooper MA, Fehniger TA and Caligiuri MA: The biology of human natural killer-cell subsets. Trends Immunol 22: 633-640, 2001.

14. Sojka DK, Plougastel-Douglas B, Yang L, Pak-Wittel MA, Artyomov MN, Ivanova Y, Zhong C, Chase JM, Rothman PB $\mathrm{Yu}$ J, et al: Tissue-resident natural killer (NK) cells are cell lineages distinct from thymic and conventional splenic NK cells. Elife 3: e01659, 2014.

15. Tang L, Peng H, Zhou J, Chen Y, Wei H, Sun R, Yokoyama WM and Tian Z: Differential phenotypic and functional properties of liver-resident NK cells and mucosal ILC1s. J Autoimmun 67: 29-35, 2016.

16. Björkström NK, Ljunggren HG and Michaëlsson J: Emerging insights into natural killer cells in human peripheral tissues. Nat Rev Immunol 16: 310-320, 2016.

17. Lugthart G, Melsen JE, Vervat C, van Ostaijen-Ten Dam MM, Corver WE, Roelen DL, van Bergen J, van Tol MJ, Lankester AC and Schilham MW: Human lymphoid tissues harbor a distinct CD69+CXCR6+ NK cell population. J Immunol 197: 78-84, 2016.

18. Marquardt N, Kekäläinen E, Chen P, Lourda M, Wilson JN, Scharenberg M, Bergman P, Al-Ameri M, Hård J, Mold JE, et al: Unique transcriptional and protein-expression signature in human lung tissue-resident NK cells. Nat Commun 10: 3841, 2019.

19. Cooper MA, Fehniger TA, Turner SC, Chen KS, Ghaheri BA, Ghayur T, Carson WE and Caligiuri MA: Human natural killer cells: A unique innate immunoregulatory role for the CD56(bright) subset. Blood 97: 3146-3151,2001.

20. Fehniger TA and Caligiuri MA: Interleukin 15: Biology and relevance to human disease. Blood 97: 14-32, 2001.

21. Wagner JA, Rosario M, Romee R, Berrien-Elliott MM, Schneider SE, Leong JW, Sullivan RP, Jewell BA, Becker-Hapak M, Schappe T, et al: CD56bright NK cells exhibit potent antitumor responses following IL-15 priming. J Clin Invest 127: 4042-4058, 2017.
22. Fauriat $\mathrm{C}$, Long EO, Ljunggren $\mathrm{HG}$ and Bryceson $\mathrm{YT}$ : Regulation of human NK-cell cytokine and chemokine production by target cell recognition. Blood 115: 2167-2176, 2010.

23. Caligiuri MA, Zmuidzinas A, Manley TJ, Levine H, Smith KA and Ritz J: Functional consequences of interleukin 2 receptor expression on resting human lymphocytes. Identification of a novel natural killer cell subset with high affinity receptors. J Exp Med 171: 1509-1526, 1990.

24. Nagler A, Lanier LL and Phillips JH: Constitutive expression of high affinity interleukin 2 receptors on human CD16-natural killer cells in vivo. J Exp Med 171: 1527-1533, 1990.

25. Leibson PJ: Signal transduction during natural killer cell activation: Inside the mind of a killer. Immunity 6: 655-661, 1997.

26. Lanier LL: On guard-activating NK cell receptors. Nat Immunol 2: 23-27, 2001

27. Yoon SR, Kim TD and Choi I: Understanding of molecular mechanisms in natural killer cell therapy. Exp Mol Med 47: e141, 2015.

28. Moretta L, Bottino C, Pende D, Mingari MC, Biassoni R and Moretta A: Human natural killer cells: Their origin, receptors and function. Eur J Immunol 32: 1205-1211, 2002.

29. Ljunggren HG and Kärre K: In search of the 'missing self': MHC molecules and NK cell recognition. Immunol Today 11: 237-244, 1990.

30. Osińska I, Popko K and Demkow U: Perforin: An important player in immune response. Cent Eur J Immunol 39: 109-115, 2014.

31. SmythMJ and JohnstoneRW:RoleofTNFinlymphocyte-mediated cytotoxicity. Microsc Res Tech 50: 196-208, 2000.

32. Screpanti V, Wallin RP, Ljunggren HG and Grandien A: A central role for death receptor-mediated apoptosis in the rejection of tumors by NK cells. J Immunol 167: 2068-2073, 2001.

33. Crinier A, Narni-Mancinelli E, Ugolini S and Vivier E: SnapShot: Natural killer cells. Cell 180: 1280-1280.e1, 2020.

34. Lee H, Schlereth SL, Park EY, Emami-Naeini P, Chauhan SK and Dana R: A novel pro-angiogenic function for interferon- $\gamma$-secreting natural killer cells. Invest Ophthalmol Vis Sci 55: 2885-2892, 2014.

35. Martín-Fontecha A, Thomsen LL, Brett S, Gerard C, Lipp M, Lanzavecchia A and Sallusto F: Induced recruitment of NK cells to lymph nodes provides IFN-gamma for $\mathrm{T}(\mathrm{H}) 1$ priming. Nat Immunol 5: 1260-1265, 2004.

36. Shankaran V, Ikeda H, Bruce AT, White JM, Swanson PE, Old LJ and Schreiber RD: IFNgamma and lymphocytes prevent primary tumour development and shape tumour immunogenicity. Nature 410: 1107-1111, 2001.

37. Zhang M, Wen B, Anton OM, Yao Z, Dubois S, Ju W, Sato N, DiLillo DJ, Bamford RN, Ravetch JV and Waldmann TA: IL-15 enhanced antibody-dependent cellular cytotoxicity mediated by NK cells and macrophages. Proc Natl Acad Sci USA 115: E10915-E10924, 2018.

38. Malmberg KJ, Carlsten M, Björklund A, Sohlberg E, Bryceson YT and Ljunggren HG: Natural killer cell-mediated immunosurveillance of human cancer. Semin Immunol 31: 20-29, 2017.

39. Fu X, Yang B, Lao S, Fan Y and Wu C: Human memory-like NK cells migrating to tuberculous pleural fluid via IP-10/CXCR3 and SDF-1/CXCR4 axis produce IFN- $\gamma$ in response to Bacille Calmette Guerin. Clin Immunol 148: 113-123, 2013.

40. Culley FJ: Natural killer cells in infection and inflammation of the lung. Immunology 128: 151-163, 2009.

41. Grégoire C, Chasson L, Luci C, Tomasello E, Geissmann F, Vivier E and Walzer T: The trafficking of natural killer cells. Immunol Rev 220: 169-182, 2007.

42. Trinchieri G: Biology of natural killer cells. Adv Immunol 47: 187-376, 1989.

43. Hervier B, Russick J, Cremer I and Vieillard V: NK cells in the human lungs. Front Immunol 10: 1263, 2019.

44. Ge N, Nishioka Y, Nakamura Y, Okano Y, Yoneda K, Ogawa H, Sugita A, Yanagawa $\mathrm{H}$ and Sone S: Synthesis and secretion of interleukin-15 by freshly isolated human bronchial epithelial cells. Int Arch Allergy Immunol 135: 235-242, 2004.

45. Shi FD, Ljunggren HG, La Cava A and Van Kaer L: Organ-specific features of natural killer cells. Nat Rev Immunol 11: 658-671, 2011.

46. Ma A, Koka R and Burkett P: Diverse functions of IL-2, IL-15, and IL-7 in lymphoid homeostasis. Annu Rev Immunol 24: 657-679, 2006

47. Floros T and Tarhini AA: Anticancer cytokines: Biology and clinical effects of interferon- $\alpha 2$, interleukin (IL)-2, IL-15, IL-21, and IL-12. Semin Oncol 42: 539-548, 2015. 
48. Tomasello E, Yessaad N, Gregoire E, Hudspeth K, Luci C, Mavilio D, Hardwigsen J and Vivier E: Mapping of NKp46(+) cells in healthy human lymphoid and non-lymphoid tissues. Front Immunol 3: 344, 2012.

49. Wang J, Li F, Zheng M, Sun R, Wei H and Tian Z: Lung natural killer cells in mice: Phenotype and response to respiratory infection. Immunology 137: 37-47, 2012.

50. Marquardt N, Kekäläinen E, Chen P, Kvedaraite E, Wilson JN Ivarsson MA, Mjösberg J, Berglin L, Säfholm J, Manson ML, et al: Human lung natural killer cells are predominantly comprised of highly differentiated hypofunctional CD69-CD56 ${ }^{\mathrm{dim}}$ cells. J Allergy Clin Immunol 139: 1321-1330.e4, 2017.

51. Robinson BW, Pinkston P and Crystal RG: Natural killer cells are present in the normal human lung but are functionally impotent. J Clin Invest 74: 942-950, 1984.

52. Weissman DN, deShazo RD and Banks DE: Modulation of natural killer cell function by human alveolar macrophages. J Allergy Clin Immunol 78 (4 Pt 1): 571-577, 1986.

53. Cooper GE, Ostridge K, Khakoo SI, Wilkinson TMA and Staples KJ: Human CD49a(+) lung natural killer cell cytotoxicity in response to influenza a virus. Front Immunol 9: 1671, 2018.

54. Roder JC, Haliotis T, Klein M, Korec S, Jett JR, Ortaldo J, Heberman RB, Katz P and Fauci AS: A new immunodeficiency disorder in humans involving NK cells. Nature 284: 553-555, 1980

55. Sullivan JL, Byron KS, Brewster FE and Purtilo DT: Deficient natural killer cell activity in x-linked lymphoproliferative syndrome. Science 210: 543-545, 1980.

56. Pross HF and Lotzová E: Role of natural killer cells in cancer Nat Immun 12: 279-292, 1993

57. Imai K, Matsuyama S, Miyake S, Suga K and Nakachi K: Natural cytotoxic activity of peripheral-blood lymphocytes and cancer incidence: An 11-year follow-up study of a general population. Lancet 356: 1795-1799, 2000.

58. Schantz SP and Ordonez NG: Quantitation of natural killer cell function and risk of metastatic poorly differentiated head and neck cancer. Nat Immun Cell Growth Regul 10: 278-288, 1991.

59. Schantz SP, Savage HE, Racz T, Taylor DL and Sacks PG: Natural killer cells and metastases from pharyngeal carcinoma. Am J Surg 158: 361-366, 1989.

60. Tartter PI, Steinberg B, Barron DM and Martinelli G: The prognostic significance of natural killer cytotoxicity in patients with colorectal cancer. Arch Surg 122: 1264-1268, 1987.

61. Cong J, Wang X, Zheng X, Wang D, Fu B, Sun R, Tian Z and Wei H: Dysfunction of natural killer cells by FBP1-induced inhibition of glycolysis during lung cancer progression. Cell Metab 28: 243-255.e5, 2018.

62. Takeda K, Nakayama M, Sakaki M, Hayakawa Y, Imawari M, Ogasawara K, Okumura K and Smyth MJ: IFN- $\gamma$ production by lung NK cells is critical for the natural resistance to pulmonary metastasis of B16 melanoma in mice. J Leukoc Biol 90: 777-785, 2011.

63. Villegas FR, Coca S, Villarrubia VG, Jiménez R, Chillón MJ, Jareño J, Zuil M and Callol L: Prognostic significance of tumor infiltrating natural killer cells subset CD57 in patients with squamous cell lung cancer. Lung Cancer 35: 23-28, 2002.

64. Takanami I, Takeuchi K and Giga M: The prognostic value of natural killer cell infiltration in resected pulmonary adenocarcinoma. J Thorac Cardiovasc Surg 121: 1058-1063, 2001.

65. Jin S, Deng Y, Hao JW, Li Y, Liu B, Yu Y, Shi FD and Zhou QH NK cell phenotypic modulation in lung cancer environment. PLoS One 9: e109976, 2014.

66. Muntasell A, Rojo F, Servitja S, Rubio-Perez C, Cabo M, Tamborero D, Costa-García M, Martínez-Garcia M, Menéndez S, Vazquez I, et al: NK cell infiltrates and HLA class I expression in primary HER $2^{+}$breast cancer predict and uncouple pathological response and disease-free survival. Clin Cancer Res 25 $1535-1545,2019$

67. Eckl J, Buchner A, Prinz PU, Riesenberg R, Siegert SI, Kammerer R, Nelson PJ and Noessner E: Transcript signature predicts tissue NK cell content and defines renal cell carcinoma subgroups independent of TNM staging. J Mol Med (Berl) 90: 55-66, 2012

68. Carrega P, Morandi B, Costa R, Frumento G, Forte G, Altavilla G, Ratto GB, Mingari MC, Moretta L and Ferlazzo G: Natural killer cells infiltrating human nonsmall-cell lung cancer are enriched in CD56 bright CD16(-) cells and display an impaired capability to kill tumor cells. Cancer 112: 863-875, 2008.

69. Platonova S, Cherfils-Vicini J, Damotte D, Crozet L, Vieillard V, Validire P, André P, Dieu-Nosjean MC, Alifano M, Régnard JF, et al: Profound coordinated alterations of intratumoral NK cell phenotype and function in lung carcinoma. Cancer Res 71: 5412-5422, 2011.
70. Schleypen JS, Baur N, Kammerer R, Nelson PJ, Rohrmann K, Gröne EF, Hohenfellner M, Haferkamp A, Pohla H, Schendel DJ, et al: Cytotoxic markers and frequency predict functional capacity of natural killer cells infiltrating renal cell carcinoma. Clin Cancer Res 12 (3 Pt 1): 718-725, 2006.

71. Melero I, Rouzaut A, Motz GT and Coukos G: T-cell and NK-cell infiltration into solid tumors: A key limiting factor for efficacious cancer immunotherapy. Cancer Discov 4: 522-526, 2014.

72. Cantoni C, Huergo-Zapico L, Parodi M,Pedrazzi M, Mingari MC, Moretta A, Sparatore B, Gonzalez S, Olive D, Bottino C, et al: NK cells, tumor cell transition, and tumor progression in solid malignancies: New Hints for NK-based immunotherapy? J Immunol Res 2016: 4684268, 2016

73. Gonzalez-Gugel E, Saxena M and Bhardwaj N: Modulation of innate immunity in the tumor microenvironment. Cancer Immunol Immunother 65: 1261-1268, 2016.

74. Lavin Y, Kobayashi S, Leader A, Amir ED, Elefant N, Bigenwald C, Remark R, Sweeney R, Becker CD, Levine JH, et al: Innate immune landscape in early lung adenocarcinoma by paired single-cell analyses. Cell 169: 750-765.e17, 2017.

75. Buckley CD and Simmons DL: Sticky moments with sticky molecules. Immunol Today 21: 601-603, 2000.

76. Campbell JJ, Qin S, Unutmaz D, Soler D, Murphy KE, Hodge MR, Wu L and Butcher EC: Unique subpopulations of CD56+ NK and NK-T peripheral blood lymphocytes identified by chemokine receptor expression repertoire. J Immunol 166: 6477-6482, 2001.

77. Böhm W, Thoma S, Leithäuser F, Möller P, Schirmbeck R and Reimann J: T cell-mediated, IFN-gamma-facilitated rejection of murine B16 melanomas. J Immunol 161: 897-908, 1998.

78. Spear P, Barber A, Rynda-Apple A and Sentman CL: Chimeric antigen receptor $\mathrm{T}$ cells shape myeloid cell function within the tumor microenvironment through IFN- $\gamma$ and GM-CSF. J Immunol 188: 6389-6398, 2012.

79. Cremer I, Fridman WH and Sautès-Fridman C: Tumor microenvironment in NSCLC suppresses NK cells function. Oncoimmunology 1: 244-246, 2012.

80. Guillerey C and Smyth MJ: NK cells and cancer immunoediting. Curr Top Microbiol Immunol 395: 115-145, 2016.

81. Belli C, Trapani D, Viale G, D'Amico P, Duso BA, Della Vigna P, Orsi $\mathrm{F}$ and Curigliano $\mathrm{G}$ : Targeting the microenvironment in solid tumors. Cancer Treat Rev 65: 22-32, 2018.

82. Vitale M, Cantoni C, Pietra G, Mingari MC and Moretta L: Effect of tumor cells and tumor microenvironment on NK-cell function. Eur J Immunol 44: 1582-1592, 2014.

83. Fauriat C, Just-Landi S, Mallet F, Arnoulet C, Sainty D, Olive D and Costello RT: Deficient expression of NCR in NK cells from acute myeloid leukemia: Evolution during leukemia treatment and impact of leukemia cells in NCRdull phenotype induction. Blood 109: 323-330, 2007.

84. Carlsten M, Norell H, Bryceson YT, Poschke I, Schedvins K, Ljunggren HG, Kiessling R and Malmberg KJ: Primary human tumor cells expressing CD155 impair tumor targeting by down-regulating DNAM-1 on NK cells. J Immunol 183 4921-4930, 2009

85. Zhang Q, Bi J, Zheng X, Chen Y, Wang H, Wu W, Wang Z, Wu Q, Peng $\mathrm{H}$, Wei $\mathrm{H}$, et al: Blockade of the checkpoint receptor TIGIT prevents NK cell exhaustion and elicits potent anti-tumor immunity. Nat Immunol 19: 723-732, 2018.

86. Castriconi R, Cantoni C, Della Chiesa M, Vitale M, Marcenaro E, Conte R, Biassoni R, Bottino C, Moretta L and Moretta A: Transforming growth factor beta 1 inhibits expression of NKp30 and NKG2D receptors: Consequences for the NK-mediated killing of dendritic cells. Proc Natl Acad Sci USA 100: 4120-4125, 2003

87. Marcenaro E, Della Chiesa M, Bellora F, Parolini S, Millo R, Moretta L and Moretta A: IL-12 or IL-4 prime human NK cells to mediate functionally divergent interactions with dendritic cells or tumors. J Immunol 174: 3992-3998, 2005.

88. Pietra G, Manzini C, Rivara S, Vitale M, Cantoni C, Petretto A, Balsamo M, Conte R, Benelli R, Minghelli S, et al: Melanoma cells inhibit natural killer cell function by modulating the expression of activating receptors and cytolytic activity. Cancer Res 72 : $1407-1415,2012$

89. Massagué J: TGFbeta in cancer. Cell 134: 215-230, 2008.

90. Bruno A, Focaccetti C, Pagani A, Imperatori AS, Spagnoletti M, Rotolo N, Cantelmo AR, Franzi F, Capella C, Ferlazzo G, et al: The proangiogenic phenotype of natural killer cells in patients with non-small cell lung cancer. Neoplasia 15: 133-142, 2013

91. Kim TK, Mo EK, Yoo CG, Lee CT, Han SK, Shim YS and Kim YW: Alteration of cell growth and morphology by overexpression of transforming growth factor beta type II receptor in human lung adenocarcinoma cells. Lung Cancer 31: 181-191, 2001. 
92.Li J, Shen C, Wang X, Lai Y, Zhou K, Li P, Liu L and Che G: Prognostic value of TGF-beta in lung cancer: Systematic review and meta-analysis. BMC Cancer 19: 691, 2019.

93. Laouar Y, Sutterwala FS, Gorelik L and Flavell RA: Transforming growth factor-beta controls $\mathrm{T}$ helper type 1 cell development through regulation of natural killer cell interferon-gamma. Nat Immunol 6: 600-607, 2005.

94. Lee JC, Lee KM, Kim DW and Heo DS: Elevated TGF-beta1 secretion and down-modulation of NKG2D underlies impaired NK cytotoxicity in cancer patients. J Immunol 172: 7335-7340, 2004.

95. Kopp HG, Placke T and Salih HR: Platelet-derived transforming growth factor-beta down-regulates NKG2D thereby inhibiting natural killer cell antitumor reactivity. Cancer Res 69: $7775-7783,2009$.

96. Sun C, Xu J, Huang Q, Huang M, Wen H, Zhang C, Wang J, Song J, Zheng M, Sun H, et al: High NKG2A expression contributes to NK cell exhaustion and predicts a poor prognosis of patients with liver cancer. Oncoimmunology 6: e1264562, 2016

97. Beldi-Ferchiou A, Lambert M, Dogniaux S, Vély F, Vivier E, Olive D, Dupuy S, Levasseur F, Zucman D, Lebbé C, et al: PD-1 mediates functional exhaustion of activated NK cells in patients with Kaposi sarcoma. Oncotarget 7: 72961-72977, 2016.

98. Li F, Wei H, Wei H, Gao Y, Xu L, Yin W, Sun R and Tian Z: Blocking the natural killer cell inhibitory receptor NKG2A increases activity of human natural killer cells and clears hepatitis B virus infection in mice. Gastroenterology 144: 392-401, 2013.

99. Bassani B, Baci D, Gallazzi M, Poggi A, Bruno A and Mortara L: Natural killer cells as key players of tumor progression and angiogenesis: Old and novel tools to divert their pro-tumor activities into potent anti-tumor effects. Cancers (Basel) 11: 461, 2019.

100.Kim JI, Lakshmikanthan V, Frilot N and Daaka Y: Prostaglandin E2 promotes lung cancer cell migration via EP4-betaArrestin1-c-Src signalsome. Mol Cancer Res 8: 569-577, 2010.

101. Balsamo M, Vermi W,Parodi M,Pietra G, Manzini C, Queirolo P, Lonardi S, Augugliaro R, Moretta A, Facchetti F, et al: Melanoma cells become resistant to NK-cell-mediated killing when exposed to NK-cell numbers compatible with NK-cell infiltration in the tumor. Eur J Immunol 42: 1833-1842, 2012.

102.Li T, Yang Y, Hua X, Wang G, Liu W, Jia C, Tai Y, Zhang Q and Chen G: Hepatocellular carcinoma-associated fibroblasts trigger NK cell dysfunction via PGE2 and IDO. Cancer Lett 318 $154-161,2012$

103. Li T, Yi S, Liu W, Jia C, Wang G, Hua X, Tai Y, Zhang Q and Chen G: Colorectal carcinoma-derived fibroblasts modulate natural killer cell phenotype and antitumor cytotoxicity. Med Oncol 30: 663, 2013.

104. Brandau S, Trellakis S, Bruderek K, Schmaltz D, Steller G, Elian M, Suttmann H, Schenck M, Welling J, Zabel P and Lang S: Myeloid-derived suppressor cells in the peripheral blood of cancer patients contain a subset of immature neutrophils with impaired migratory properties. J Leukoc Biol 89 311-317, 2011

105. Granville CA, Memmott RM, Balogh A, Mariotti J, Kawabata S, Han W, Lopiccolo J, Foley J, Liewehr DJ, Steinberg SM, et al: A central role for Foxp3+ regulatory T cells in K-Ras-driven lung tumorigenesis. PLoS One 4: e5061, 2009.

106. Smyth MJ, Teng MW, Swann J, Kyparissoudis K, Godfrey DI and Hayakawa Y: CD4+CD25+ T regulatory cells suppress NK cell-mediated immunotherapy of cancer. J Immunol 176 $1582-1587,2006$

107. Ghiringhelli F, Ménard C, Terme M, Flament C, Taieb J, Chaput N, Puig PE, Novault S, Escudier B, Vivier E, et al $\mathrm{CD} 4+\mathrm{CD} 25+$ regulatory $\mathrm{T}$ cells inhibit natural killer cell functions in a transforming growth factor-beta-dependent manner J Exp Med 202: 1075-1085, 2005.

108. Lardner A: The effects of extracellular $\mathrm{pH}$ on immune function. J Leukoc Biol 69: 522-530, 2001.

109. Balsamo M, Manzini C, Pietra G, Raggi F, Blengio F, Mingari MC, Varesio L, Moretta L, Bosco MC and Vitale M Hypoxia downregulates the expression of activating receptors involved in NK-cell-mediated target cell killing without affecting ADCC. Eur J Immunol 43: 2756-2764, 2013.

110. Sarkar S, Germeraad WT, Rouschop KM, Steeghs EM, van Gelder M, Bos GM and Wieten L: Hypoxia induced impairment of NK cell cytotoxicity against multiple myeloma can be overcome by IL-2 activation of the NK cells. PLoS One 8 : e64835, 2013.
111. Li C, Lu HJ, Na FF, Deng L, Xue JX, Wang JW, Wang YQ, $\mathrm{Li} \mathrm{QL}$ and $\mathrm{Lu} \mathrm{Y}$ : Prognostic role of hypoxic inducible factor expression in non-small cell lung cancer: A meta-analysis. Asian Pac J Cancer Prev 14: 3607-3612, 2013.

112. Yang SL, Ren QG, Wen L and Hu JL: Clinicopathological and prognostic significance of hypoxia-inducible factor-1 alpha in lung cancer: A systematic review with meta-analysis. J Huazhong Univ Sci Technolog Med Sci 36: 321-327, 2016.

113. Vaupel P and Multhoff G: Adenosine can thwart antitumor immune responses elicited by radiotherapy: Therapeutic strategies alleviating protumor ADO activities. Strahlenther Onkol 192: 279-287, 2016.

114. Pötzl J, Roser D, Bankel L, Hömberg N, Geishauser A, Brenner CD, Weigand M, Röcken M and Mocikat R: Reversal of tumor acidosis by systemic buffering reactivates NK cells to express IFN- $\gamma$ and induces NK cell-dependent lymphoma control without other immunotherapies. Int J Cancer 140: 2125-2133, 2017

115. Husain Z, Huang Y, Seth P and Sukhatme VP: Tumor-derived lactate modifies antitumor immune response: Effect on myeloid-derived suppressor cells and NK cells. J Immunol 191: 1486-1495, 2013.

116. Sautès-Fridman C, Cherfils-Vicini J, Damotte D, Fisson S, Fridman WH, Cremer I and Dieu-Nosjean MC: Tumor microenvironment is multifaceted. Cancer Metastasis Rev 30: 13-25, 2011.

117. Mailloux AW and Young MR: NK-dependent increases in CCL22 secretion selectively recruits regulatory T cells to the tumor microenvironment. J Immunol 182: 2753-2765, 2009.

118. Srivastava S, Pelloso D, Feng H, Voiles L, Lewis D, Haskova Z, Whitacre M, Trulli S, Chen YJ, Toso J, et al: Effects of interleukin-18 on natural killer cells: Costimulation of activation through Fc receptors for immunoglobulin. Cancer Immunol Immunother 62: 1073-1082, 2013.

119. Mi D, Ren W and Yang K: Adoptive immunotherapy with interleukin-2 \& induced killer cells in non-small cell lung cancer: A systematic review \& meta-analysis. Indian J Med Res 143: S1-S10, 2016.

120. Davis ZB, Felices M, Verneris MR and Miller JS: Natural killer cell adoptive transfer therapy: Exploiting the first line of defense against cancer. Cancer J 21: 486-491, 2015.

121. Ito S, Bollard CM, Carlsten M, Melenhorst JJ, Biancotto A Wang E, Chen J, Kotliarov Y, Cheung F, Xie Z, et al: Ultra-low dose interleukin-2 promotes immune-modulating function of regulatory $\mathrm{T}$ cells and natural killer cells in healthy volunteers. Mol Ther 22: 1388-1395, 2014

122. Waldmann TA: The biology of interleukin-2 and interleukin-15: Implications for cancer therapy and vaccine design. Nat Rev Immunol 6: 595-601, 2006.

123. Miller JS, Morishima C, McNeel DG, Patel MR, Kohrt HEK, Thompson JA, Sondel PM, Wakelee HA, Disis ML, Kaiser JC, et al: A first-in-human phase I study of subcutaneous outpatient recombinant human IL15 (rhIL15) in adults with advanced solid tumors. Clin Cancer Res 24: 1525-1535, 2018.

124. Wong HC, Jeng EK and Rhode PR: The IL-15-based superagonist ALT-803 promotes the antigen-independent conversion of memory $\mathrm{CD} 8^{+} \mathrm{T}$ cells into innate-like effector cells with antitumor activity. Oncoimmunology 2: e26442, 2013

125. Wrangle JM, Velcheti V, Patel MR, Garrett-Mayer E, Hill EG, Ravenel JG, Miller JS, Farhad M, Anderton K, Lindsey K, et al: ALT-803, an IL-15 superagonist, in combination with nivolumab in patients with metastatic non-small cell lung cancer: A non-randomised, open-label, phase $1 \mathrm{~b}$ trial. Lancet Oncol 19: 694-704, 2018

126. Bowles JA, Wang SY, Link BK, Allan B, Beuerlein G, Campbell MA, Marquis D, Ondek B, Wooldridge JE, Smith BJ, et al: Anti-CD20 monoclonal antibody with enhanced affinity for CD16 activates NK cells at lower concentrations and more effectively than rituximab. Blood 108: 2648-2654, 2006.

127. Decaup E, Rossi C, Gravelle P, Laurent C, Bordenave J, Tosolini M, Tourette A, Perrial E, Dumontet C, Poupot M, et al: A tridimensional model for NK cell-mediated ADCC of follicular lymphoma. Front Immunol 10: 1943, 2019.

128. Mallmann-Gottschalk N, Sax Y, Kimmig R, Lang S and Brandau S: EGFR-specific tyrosine kinase inhibitor modifies NK cell-mediated antitumoral activity against ovarian cancer cells. Int J Mol Sci 20: 4693, 2019.

129. André P, Denis C, Soulas C, Bourbon-Caillet C, Lopez J, Arnoux T, Bléry M, Bonnafous C, Gauthier L, Morel A, et al: Anti-NKG2A mAb Is a checkpoint inhibitor that promotes anti-tumor immunity by unleashing both T and NK cells. Cell 175: 1731-1743.e13, 2018. 
130. Lin M, Luo H, Liang S, Chen J, Liu A, Niu L and Jiang Y: Pembrolizumab plus allogeneic NK cells in advanced non-small cell lung cancer patients. J Clin Invest 130: 2560-2569, 2020.

131. Youn JI, Park SM, Park S, Kim G, Lee HJ, Son J, Hong MH, Ghaderpour A, Baik B, Islam J, et al: Peripheral natural killer cells and myeloid-derived suppressor cells correlate with anti-PD-1 responses in non-small cell lung cancer. Sci Rep 10: 9050, 2020.

132. Trefny MP, Kaiser M, Stanczak MA, Herzig P, Savic S, Wiese M, Lardinois D, Läubli H, Uhlenbrock F and Zippelius A PD- $1^{+}$natural killer cells in human non-small cell lung cancer can be activated by PD-1/PD-L1 blockade. Cancer Immunol Immunother 69: 1505-1517, 2020.

133. Paz-Ares L, Luft A, Vicente D, Tafreshi A, Gümüş M, Mazières J, Hermes B, Cay Senler F, Csőszi T, Fülöp A, et al: Pembrolizumab plus chemotherapy for squamous non-small-cell lung cancer. N Engl J Med 379: 2040-2051, 2018.

134. Mok TSK, Wu YL, Kudaba I, Kowalski DM, Cho BC, Turna HZ, Castro G Jr, Srimuninnimit V, Laktionov KK, Bondarenko I, et al: Pembrolizumab versus chemotherapy for previously untreated, PD-L1-expressing, locally advanced or metastatic non-small-cell lung cancer (KEYNOTE-042): A randomised, open-label, controlled, phase 3 trial. Lancet 393: 1819-1830, 2019.

135. Lisberg A, Cummings A, Goldman JW, Bornazyan K, Reese N, Wang T, Coluzzi P, Ledezma B, Mendenhall M, Hunt J, et al: A phase II study of pembrolizumab in EGFR-Mutant, PD-L1+ tyrosine kinase inhibitor naïve patients with advanced NSCLC. J Thorac Oncol 13: 1138-1145, 2018.

136. Chabannon C, Mfarrej B, Guia S, Ugolini S, Devillier R, Blaise D, Vivier E and Calmels B: Manufacturing natural killer cells as medicinal products. Front Immunol 7: 504, 2016

137. Carotta S: Targeting NK cells for anticancer immunotherapy: Clinical and preclinical approaches. Front Immunol 7: 152, 2016.

138. Sakamoto N, Ishikawa T, Kokura S, Okayama T, Oka K, Ideno M, Sakai F, Kato A, Tanabe M, Enoki T, et al: Phase I clinical trial of autologous NK cell therapy using novel expansion method in patients with advanced digestive cancer. J Trans Med 13: 277, 2015

139. Parkhurst MR, Riley JP, Dudley ME and Rosenberg SA: Adoptive transfer of autologous natural killer cells leads to high levels of circulating natural killer cells but does not mediate tumor regression. Clin Cancer Res 17: 6287-6297, 2011.

140. Benson DM Jr, Bakan CE, Zhang S, Collins SM, Liang J, Srivastava S, Hofmeister CC, Efebera Y, Andre P, Romagne F, et al: IPH2101, a novel anti-inhibitory KIR antibody, and lenalidomide combine to enhance the natural killer cell versus multiple myeloma effect. Blood 118: 6387-6391, 2011

141. Ruggeri L, Capanni M, Urbani E, Perruccio K, Shlomchik WD, Tosti A,Posati S, Rogaia D,FrassoniF, Aversa F, etal: Effectiveness of donor natural killer cell alloreactivity in mismatched hematopoietic transplants. Science 295: 2097-2100, 2002.

142. Calvo T, Reina-Ortiz C, Giraldos D, Gascón M, Woods D, Asenjo J, Marco-Brualla J, Azaceta G, Izquierdo I, Palomera L, et al: Expanded and activated allogeneic NK cells are cytotoxic against B-chronic lymphocytic leukemia (B-CLL) cells with sporadic cases of resistance. Sci Rep 10: 19398, 2020.

143. Miller JS, Soignier Y, Panoskaltsis-Mortari A, McNearney SA, Yun GH, Fautsch SK, McKenna D, Le C, Defor TE, Burns LJ, et al: Successful adoptive transfer and in vivo expansion of human haploidentical NK cells in patients with cancer. Blood 105: 3051-3057, 2005.

144. Cheng M, Chen Y, Xiao W, Sun R and Tian Z: NK cell-based immunotherapy for malignant diseases. Cell Mol Immunol 10 230-252, 2013.

145. Jochems C, Hodge JW, Fantini M, Fujii R, Morillon YM II, Greiner JW, Padget MR, Tritsch SR, Tsang KY, Campbell KS, et al: An NK cell line (haNK) expressing high levels of granzyme and engineered to express the high affinity CD16 allele. Oncotarget 7: 86359-86373, 2016.

146. Park HR, Ahn YO, Kim TM, Kim S, Kim S, Lee YS, Kim M, Keam B, Kim DW and Heo DS: NK92-CD16 cells are cytotoxic to non-small cell lung cancer cell lines that have acquired resistance to tyrosine kinase inhibitors. Cytotherapy 21: 603-611, 2019.

147. Iliopoulou EG, Kountourakis P, Karamouzis MV, Doufexis D, Ardavanis A, Baxevanis CN, Rigatos G, Papamichail M and Perez SA: A phase I trial of adoptive transfer of allogeneic natural killer cells in patients with advanced non-small cell lung cancer. Cancer Immunol Immunother 59: 1781-1789, 2010.
148. Wu C: Heat shock transcription factors: Structure and regulation. Annu Rev Cell Dev Biol 11: 441-469, 1995

149. Kregel KC: Heat shock proteins: Modifying factors in physiological stress responses and acquired thermotolerance. J Appl Physiol (1985) 92: 2177-2186, 2002.

150. Guzhova IV and Margulis BA: HSP70-based anti-cancer immunotherapy. Hum Vaccin Immunother 12: 2529-2535, 2016.

151. Lazarev VF, Nikotina AD, Mikhaylova ER, Nudler E, Polonik SG, Guzhova IV and Margulis BA: Hsp70 chaperone rescues $\mathrm{C} 6$ rat glioblastoma cells from oxidative stress by sequestration of aggregating GAPDH. Biochem Biophys Res Commun 470: 766-771, 2016.

152. Calderwood SK and Gong J: Heat shock proteins promote cancer: It's a protection racket. Trends Biochem Sci 41: 311-323, 2016.

153. Mittal S and Rajala MS: Heat shock proteins as biomarkers of lung cancer. Cancer Biol Ther 21: 477-485, 2020.

154. Jin HO, Hong SE, Kim JY, Kim MR, Chang YH, Hong YJ, Lee JK and Park IC: Induction of HSP27 and HSP70 by constitutive overexpression of Redd1 confers resistance of lung cancer cells to ionizing radiation. Oncol Rep 41: 3119-3126, 2019

155. Hromadnikova I, Pirkova P and Sedlackova L: Influence of in vitro IL-2 or IL-15 alone or in combination with Hsp-70-derived 14-mer peptide (TKD) on the expression of NK cell activatory and inhibitory receptors. Mediators Inflamm 2013: 405295, 2013.

156. Multhoff G, Seier S, Stangl S, Sievert W, Shevtsov M, Werner C Pockley AG, Blankenstein C, Hildebrandt M, Offner R, et al: Targeted natural killer cell-based adoptive immunotherapy for the treatment of patients with NSCLC after radiochemotherapy: A randomized phase II clinical trial. Clin Cancer Res 26: 5368-5379, 2020.

157. Specht HM, Ahrens N, Blankenstein C, Duell T, Fietkau R, Gaipl US, Günther C, Gunther S, Habl G, Hautmann H, et al: Heat shock protein 70 (Hsp70) peptide activated natural killer (NK) cells for the treatment of patients with non-small cell lung cancer (NSCLC) after radiochemotherapy (RCTx)-from preclinical studies to a clinical phase II trial. Front Immunol 6: $162,2015$.

158. Shevtsov M, Pitkin E, Ischenko A, Stangl S, Khachatryan W, Galibin O, Edmond S, Lobinger D and Multhoff G: Ex vivo Hsp70-activated nk cells in combination with PD-1 inhibition significantly increase overall survival in preclinical models of glioblastoma and lung cancer. Front Immunol 10: 454, 2019.

159. Daher $M$ and Rezvani K: Next generation natural killer cells for cancer immunotherapy: The promise of genetic engineering. Curr Opin Immunol 51: 146-153, 2018

160. Xie G, Dong H, Liang Y, Ham JD, Rizwan R and Chen J: CAR-NK cells: A promising cellular immunotherapy for cancer. EBioMedicine 59: 102975, 2020.

161. Wang W, Jiang J and Wu C: CAR-NK for tumor immunotherapy: Clinical transformation and future prospects. Cancer Lett 472 $175-180,2020$

162. Hu Y, Tian ZG and Zhang C: Chimeric antigen receptor (CAR)-transduced natural killer cells in tumor immunotherapy. Acta Pharmacol Sin 39: 167-176, 2018.

163. Oei VYS, Siernicka M, Graczyk-Jarzynka A, Hoel HJ, Yang W, Palacios D, Almåsbak H, Bajor M, Clement D, Brandt L, et al: Intrinsic functional potential of NK-cell subsets constrains retargeting driven by chimeric antigen receptors. Cancer Immunol Res 6: 467-480, 2018.

164. Liu E, Tong Y, Dotti G, Shaim H, Savoldo B, Mukherjee M, Orange J, Wan X, Lu X, Reynolds A, et al: Cord blood NK cells engineered to express IL-15 and a CD19-targeted CAR show long-term persistence and potent antitumor activity. Leukemia 32: 520-531, 2018

165. Liu E, Marin D, Banerjee P, Macapinlac HA, Thompson P, Basar R, Nassif Kerbauy L, Overman B, Thall P, Kaplan M, et al: Use of CAR-transduced natural killer cells in CD19-positive lymphoid tumors. N Engl J Med 382: 545-553, 2020.

166. Gunesch JT, Angelo LS, Mahapatra S, Deering RP, Kowalko JE, Sleiman P, Tobias JW, Monaco-Shawver L, Orange JS and Mace EM: Genome-wide analyses and functional profiling of human NK cell lines. Mol Immunol 115: 64-75, 2019.

167. Liu Q, Xu Y, Mou J, Tang K, Fu X, Li Y, Xing Y, Rao Q, Xing H, Tian Z, et al: Irradiated chimeric antigen receptor engineered NK-92MI cells show effective cytotoxicity against CD19+ malignancy in a mouse model. Cytotherapy 22: 552-562, 2020.

168. Yang S, Cao B, Zhou G, Zhu L, Wang L, Zhang L, Kwok HF, Zhang Z and Zhao Q: Targeting B7-H3 immune checkpoint with chimeric antigen receptor-engineered natural killer cells exhibits potent cytotoxicity against non-small cell lung cancer. Front Pharmacol 11: 1089, 2020 . 
169. Tonn T, Schwabe D, Klingemann HG, Becker S, Esser R, Koehl U, Suttorp M, Seifried E, Ottmann OG and Bug G: Treatment of patients with advanced cancer with the natural killer cell line NK-92. Cytotherapy 15: 1563-1570, 2013.

170. Lu C, Guo C, Chen H, Zhang H, Zhi L, Lv T, Li M, Niu Z, Lu P and Zhu W: A novel chimeric PD1-NKG2D-41BB receptor enhances antitumor activity of NK92 cells against human lung cancer H1299 cells by triggering pyroptosis. Mol Immunol 122: 200-206, 2020.

171. Shah NN, Baird K, Delbrook CP, Fleisher TA, Kohler ME, Rampertaap S, Lemberg K, Hurley CK, Kleiner DE, Merchant MS, et al: Acute GVHD in patients receiving IL-15/4-1BBL activated NK cells following T-cell-depleted stem cell transplantation. Blood 125: 784-792, 2015.

172. Klingemann $\mathrm{H}$ : Challenges of cancer therapy with natural killer cells. Cytotherapy 17: 245-249, 2015.

173. Gauthier L, Morel A, Anceriz N, Rossi B, Blanchard-Alvarez A, Grondin G, Trichard S, Cesari C, Sapet M, Bosco F, et al: Multifunctional natural killer cell engagers targeting NKp46 trigger protective tumor immunity. Cell 177: 1701-1713.e16, 2019.
174. Hodgins JJ, Khan ST, Park MM, Auer RC and Ardolino M: Killers 2.0: NK cell therapies at the forefront of cancer control. J Clin Invest 129: 3499-3510, 2019.

175. Yao C, Ni Z, Gong C, Zhu X, Wang L, Xu Z, Zhou C, Li S, Zhou W, Zou C and Zhu S: Rocaglamide enhances NK cell-mediated killing of non-small cell lung cancer cells by inhibiting autophagy. Autophagy 14: 1831-1844, 2018.

176. Lin M, Liang SZ, Wang XH, Liang YQ, Zhang MJ, Niu LZ, Chen JB, Li HB and Xu KC: Clinical efficacy of percutaneous cryoablation combined with allogenic NK cell immunotherapy for advanced non-small cell lung cancer. Immunol Res 65: 880-887, 2017.

(i) (5) $९$ This work is licensed under a Creative Commons Attribution-NonCommercial-NoDerivatives 4.0 International (CC BY-NC-ND 4.0) License. 